\title{
The Hidden American Nativist Consensus
}

Andrew Thompson

\author{
Christopher Dinkel
}

May 3, 2021

\begin{abstract}
Nativism has received recent attention because of its salience in American politics, but it dates back to the early days of the Republic. We show nativist sentiments were established in the citizenship-eligibility requirement for the presidency have since been mirrored in the American public's preferences outside of the executive. We argue that the inclusion of the natural born citizen clause in the U.S. Constitution helped set in motion public expectations for legislative and judicial office holders. Then, with a novel dataset, we show Americans who were not born in the United States have been severely underrepresented in Congress and on the Supreme Court. Finally, using two conjoint designs, we show candidates for Congress and the Supreme Court who fit a nativist mold are preferred by the public across party lines. Overall, we argue a nativist consensus exists in the public which could exacerbate inequalities of representation within American politics.
\end{abstract}

Word count: 9958 
Nativism is a concept embedded into the very fabric of the United States. Since its inception, the U.S. government has been oriented toward serving its citizens - which is to be expected with the creation of a nation-state. This sentiment was not simply a cultural phenomenon in these early moments, however; it was codified into the institutional structure of U.S. democracy. Although America has long been described as a nation of immigrants, they are institutionally barred from serving in the highest office. The U.S. Constitution is explicitly exclusionary about who can serve as president—natural born citizens. Other branches of the federal government, namely the legislature and judiciary, do not have this same formal nativist requirement for holding office. Naturalized citizens may maintain seats in Congress or on the Supreme Court. Despite this lack of institutional barriers, we show in this project that citizens who were born outside the United States have gone greatly underrepresented both in Congress and on the Supreme Court. Why have these institutions, which lack the same formal citizenship-based bulwarks of the presidency, come to mirror its orientation? We postulate that the public has taken historical and institutional cues from the executive that have culminated in robust, nativist preferences for candidates for Congress and the Supreme Court.

In this paper, we first examine the historical legacies of nativism in the formal U.S. government, describing how the concept came to be established within the citizenship-eligibility requirement for the executive and has since been mirrored in the public's expectations for the legislative and judicial branches. We view the natural born citizen clause of the U.S. Constitution as a potential origin point for how Americans think about the citizenship status of federal representatives and judges. Scholars argue that the rationale of this clause was to prevent foreign intervention in the early days of the American republic, which does help to explain the intentions behind it, but fails to describe its subsequent interpretations by the public. We focus on the latter, 
arguing that over time there have potentially been historical misinterpretations about the other branches of American government by the public because of cues from the executive. In short, people might be assuming similar criteria for being a legislator or judge as they do for the president.

Next, we provide a descriptive assessment of representation in Congress and on the Supreme Court by their members' birthplaces. With this novel data source, we ultimately show that U.S. citizens who were born outside the U.S. have been massively underrepresented in both institutions throughout their history. We argue that this is likely motivated by nativism in the electorate. The mechanisms we then sketch out in our historical discussion might help to explain the dearth of Congressmembers and Supreme Court Justices born outside the U.S., despite the fact that Americans who were born outside the U.S. make up a large portion of the public.

Finally, we experimentally test the causal power of nativism on attitudes toward elites. We use a set of unique conjoint experiments on two representative samples of the American public to evaluate how these exclusionary attitudes affect support for candidates for Congress and the Supreme Court. We specifically find that attributes which contrast with nativist ideals about candidates cause less support among American citizens. In further examination of our results, we show that Democrats and Republicans differ along attitudinal measures of nativism, yet when comparing between these groups within both of our conjoint designs, they express very similar nativist preferences for candidates.

Based on our findings from these studies, we argue that there is a "hidden nativist consensus" among the American public. This is a set of informal requirements that Americans have for political elites. These publicly imposed requirements are specifically that candidates must be born in the U.S. and only hold U.S. citizenship. We argue that this heretofore hidden 
consensus could continue to drive future support for political elites and who is represented in government, which could further exacerbate inequalities in the rapidly diversifying United States.

\section{American Cultural Tradition}

Scholars have theorized that multiple cultural traditions operate at once in the U.S (Smith 1993; 1999; Du Bois 1998). These different traditions are ascriptive hierarchies that have existed alongside, and often in conflict with, the often-emphasized traditions of liberal, democratic traditions (Tocqueville 2003; Hartz 1955). The hierarchies refer to systems of unequal status between groups in society along the lines of race, gender, religion, and nativism, among others. Within each of these group contexts, more status is assigned to some groups in ways that give them power over others. These power asymmetries exist in the midst of a liberal cultural tradition that articulates ideas about equality across all individuals. Recent empirical work has confirmed that the multiple traditions thesis still bears out in the current context among the American public (Schildkraut 2007; 2010; 2014).

Thus far, the multiple traditions thesis has been used to consider how variant American political cultures exist at once and in conflict with one another. Less attention has been given to how illiberal traditions have become manifested in liberal government and have led to political consequences. These historical narratives help connect the past to the present, showing the lasting ramifications of the multiple cultural traditions in the U.S.

We elaborate on one such illiberal tradition, nativism, by first showing how it was

codified into law in the executive, which potentially led to feedback effects in representation and broader public opinion on Congress and the Supreme Court. Although the Framers had noble, 
liberal aspirations in establishing nativist ideals in government, they have since been interpreted in ways that present issues for governing and representing Americans' interests.

\section{History of Nativism in Public Office}

The origin point of this project is the "natural born citizen" clause of the U.S. Constitution. Article Two, Section 1, sets forth the citizenship-eligibility requirement for President:

"No person except a natural born citizen, or a citizen of the United States, at the time of the adoption of this Constitution, shall be eligible to the office of President[.]"

Only natural born citizens are thus eligible for the executive. ${ }^{1}$ Legal scholars have viewed the inclusion of this clause in the Constitution as stemming from a concern over European aristocrats infiltrating the U.S. government (Reed Amar 2004) and have pointed out that it was included in the Constitution soon after John Jay sent a letter to George Washington voicing apprehension over "Foreigners" becoming the Commander in Chief. ${ }^{2}$ Although the Constitution does not define "natural born citizen," contemporary legal commentators interpret this clause to mean that the person must have been a U.S. citizen from birth — whether born in the United

\footnotetext{
${ }^{1}$ Under the 12th Amendment to the U.S. Constitution, the Vice President must be constitutionally eligible to serve as President.

2154 Cong. Rec. S3645-46 (daily ed. April 30, 2008) (letter of Theodore Olson and Laurence Tribe) (citing Chief. 3 Max Farrand, The Records of the Federal Convention of 1787, at 61 (1911)).
} 
States or outside the United States (Clement and Katyal 2015). ${ }^{3}$ However, some Americans have viewed the natural born citizen clause as only conferring eligibility for a person actually born on U.S. soil. For example, some Democrats questioned at the time whether President Chester A. Arthur, a Republican, was eligible to serve as president in 1881 due to uncertainty over whether he was born in Vermont, as he claimed, or across the border in Canada (Rocca 2012). Additionally, some Democrats in Congress, including the Chair of the U.S. House of Representatives' Committee on the Judiciary, raised concerns during the 1968 presidential election about whether Republican candidate George Romney was eligible to serve in the White House due to his birth in Mexico, even though both his parents were American. This questioning of Romney's eligibility foreshadowed arguments that Donald J. Trump and other conservative "birthers" made that Barack Obama was not born in Hawaii and therefore was ineligible to serve as President, even though Obama's mother was from Kansas (Hosenball 2012). Notably, these birther arguments persisted despite the U.S. Senate's effort to put this debate to rest when it passed a resolution by unanimous consent in 2008 asserting that Republican presidential candidate John McCain, who was born to American parents on a U.S. military base in the Panama Canal Zone, qualified as a "natural born citizen" (Slattery 2015). In doing so, the Senate asserted that "previous presidential candidates were born outside of the United States of America and were understood to be eligible to be President."

\footnotetext{
${ }^{3}$ Under the 14th Amendment to the U.S. Constitution and Congressional statute (8 U.S.C. $\left.§ 1401(a)\right)$, U.S. citizenship is granted at birth to a person if the person is born in the United States and is subject to its jurisdiction. ${ }^{4}$ 110th Cong., 2d Sess., S. Res. 511. See also 154 Cong. Rec. S3645-46 (daily ed. April 30, 2008) (statement of Sen. Leahy), citing the examples of George Romney and prior presidential candidate, U.S. Senator Barry Goldwater, who was born in a U.S territory that subsequently became the State of Arizona.
} 
The formal requirements for the Presidency are not mirrored in Congress or the Supreme Court. For Congress, candidates meet the Constitutional citizenship requirements if they have been a U.S. citizen for 7 years (House of Representatives) or 9 years (Senate). ${ }^{5}$ For the Supreme Court, there are no citizenship-eligibility requirements for Justices. Thus, neither being a U.S. citizen since birth nor being born in the United States is a Constitutional requirement for serving in Congress or on the U.S. Supreme Court. It is likely that as a result of these criteria, the public's perception of citizenship-eligibility requirements for Congress and the Supreme Court have not been given the same amount of attention as they have for the Presidency. ${ }^{6}$

Nevertheless, we believe that the nativist requirement set forth for the President in the natural born citizen clause has since been mirrored in the nativist preferences that the American public holds for Members of Congress and Supreme Court Justices. We expect that these preferences are for elites who were born in the U.S. and have been U.S. citizens their entire lives. Additionally, we anticipate that where elites hold citizenship will matter to how they are evaluated. Specifically, when they are a U.S. citizen and a citizen of another country, they will experience penalties because the public will perceive them as "foreign."

If our theory is correct, these latent nativist preferences in the American public would help to explain the discrepancy we find between the percentage of the general U.S. population born outside the U.S. and the percentage of Members of Congress and Supreme Court Justices born outside the U.S. We postulate that these inequalities are a direct outgrowth of the nativist

\footnotetext{
${ }^{5}$ U.S. Const., Art. I $\S 2,3$.

${ }^{6}$ One earlier study (Lawson 1957) provided aggregate statistics on the number of foreign-born Members of Congress from 1789-1949 but did not examine public opinion related to foreign-born Members of Congress or foreign-born Supreme Court Justices.
} 
American tradition. These inequalities could have been facilitated through a number of causal pathways over time, each of which we find to be plausible and we describe next.

The first pathway is a longstanding historical suspicion of foreigners that dates back to the colonial origins of the United States. These concerns, especially in the Early Republic Era, were motivated by a fear of foreign interference in U.S. democracy—namely, Europeans infiltrating the processes of government in order to advance their own interests (Reed Amar 2004). The causal case for this suspicion is that it became so embedded in the process of selecting political elites that the public has implicit preferences for elites who appear to be least prone to foreign influence-i.e., those who fit a nativist profile.

The second pathway is that the public has misinterpreted the requirements for holding federal office. Despite the executive being the only federal office that has nativist requirements, the American public thinks all other branches of government have the same requirements for office. Being born outside of the U.S., acquiring U.S. citizenship after birth, and/or having dual citizenship effectively excludes candidates from holding office among Americans. The main explanation for this misunderstanding is an issue in civic education about requirements for office, which is plausible given difficulties with civics in the U.S. (Youniss 2011; Banks 2017).

A third pathway, similar to the second, is that the executive has given cues to the public about expectations for office. In this pathway, preferences, not requirements, among the public are shaped. The public thinks that candidates who fit a nativist mold are categorically better than those who do not fit the mold. In this pathway, being born outside the U.S., acquiring U.S. citizenship after birth, and/or having dual citizenship is less preferable in the eyes of Americans, and candidates having those attributes will be penalized by the public. 
The last pathway is that recent rhetoric surrounding nativism has shaped attitudes toward candidate preferences. Under this explanation, current political conditions are anomalous and therefore central to public perceptions of elites. Due to political rhetoric that has been explicit about nativist sentiment (e.g., Donald Trump's anti-immigrant stances), the American public has been moved to express similar views in ways that have not been as overt as in previous eras.

Each of these four explanations plausibly describes why the public might express preferences for nativist candidates. Given the unique nature of each pathway, they could all describe the development of this nativist expectation among Americans. ${ }^{7}$ These pathways are the core mechanisms behind our expectation that the American public has come to prefer elites with nativist profiles in the federal government. Regardless of how these preferences have become established, we expect that they will all lead to the same outcome, which is the underrepresentation of elites whose citizenship history does not align with that of the prototypical native-born American. Yet up to this point, the citizenship history of elites has gone understudied in the realm of representation.

\section{Representation}

Representation concerns making citizens' perspectives and voices present in the political process. It can be done in a variety of ways, and one of the most well-known types is descriptive representation. This idea is that groups elect individuals who represent them in their characteristics and outward experiences (Mansbridge 1999; Mansbridge 2003). Groups might

\footnotetext{
${ }^{7}$ Identifying which pathway best explains the current state of public attitudes is outside of the scope of this project but deserves further inquiry.
} 
benefit from descriptive representation because there is mistrust in the system of government and/or they do not have crystallized interests.

Despite these potential benefits, descriptive characteristics of representatives have been shown to have mixed effects on support from their respective groups. For one, a series of studies has shown that descriptive representation along both race and gender has little effect upon political behavior in the way of turnout (Broockman 2014; Fraga 2015; 2016; Henderson, Sekhon, and Titiunik 2016). Specifically, these null findings are that when co-ethnic candidates and co-gender candidates run for office, there is no substantive increase in turnout for that group among the electorate.

Scholars have also found mixed effects of potential U.S. Supreme Court nominees' descriptive characteristics on the public's support for those nominees. Kaslovsky et al. (2019) find evidence of increased support for nominees who share survey respondents' race, especially among white Republicans and black Democrats, but find no similar effect with respect to gender. Sen (2017) finds that when it is provided, information about nominees' partisanship strongly predicts the public's support for those nominees, but when it is withheld, the public relies upon other demographic cues about the nominees, such as their race.

Other works have shown negative consequences of descriptive representation and barriers to entry that contribute to underrepresentation. Dissimilarity in representation causes constituents to communicate less with representatives outside of their groups (Broockman 2014). Additionally, certain groups, namely women, experience barriers to entry that contribute to their underrepresentation in office (Teele, Kalla, and Rosenbluth 2018). We postulate that descriptive 
representation for Americans born outside the U.S. operates similarly, which we first confirm descriptively. ${ }^{8}$

\section{Representation in the Legislature and the Judiciary by Birthplace}

We find that members of both Congress and the Supreme Court have been highly

unrepresentative in terms of their place of birth when compared to all U.S. citizens in the general

U.S. population. To take the current, 117th U.S. Congress as an example, according to our

calculations, only five Senators and 29 Representatives of the voting Members of Congress are

U.S. citizens who were born outside a U.S. state or the District of Columbia (D.C.). ${ }^{9}$ Across

Congress then, about $6.4 \%$ of all voting Congressmembers were born outside a U.S. state or D.C.

\footnotetext{
${ }^{8}$ This underrepresentation could be the result of candidates selecting out or losing elections, both of which we find to be plausible explanations.

${ }^{9}$ To accurately compare our data on Members of Congress with the American Community Survey data discussed below, we consider Members of Congress who were born in a territory that subsequently became a U.S. state as being born in a U.S. state for all our analyses in this section.
} 


\section{Figure 1-Voting Congressmembers of Current Congress by Birthplace}

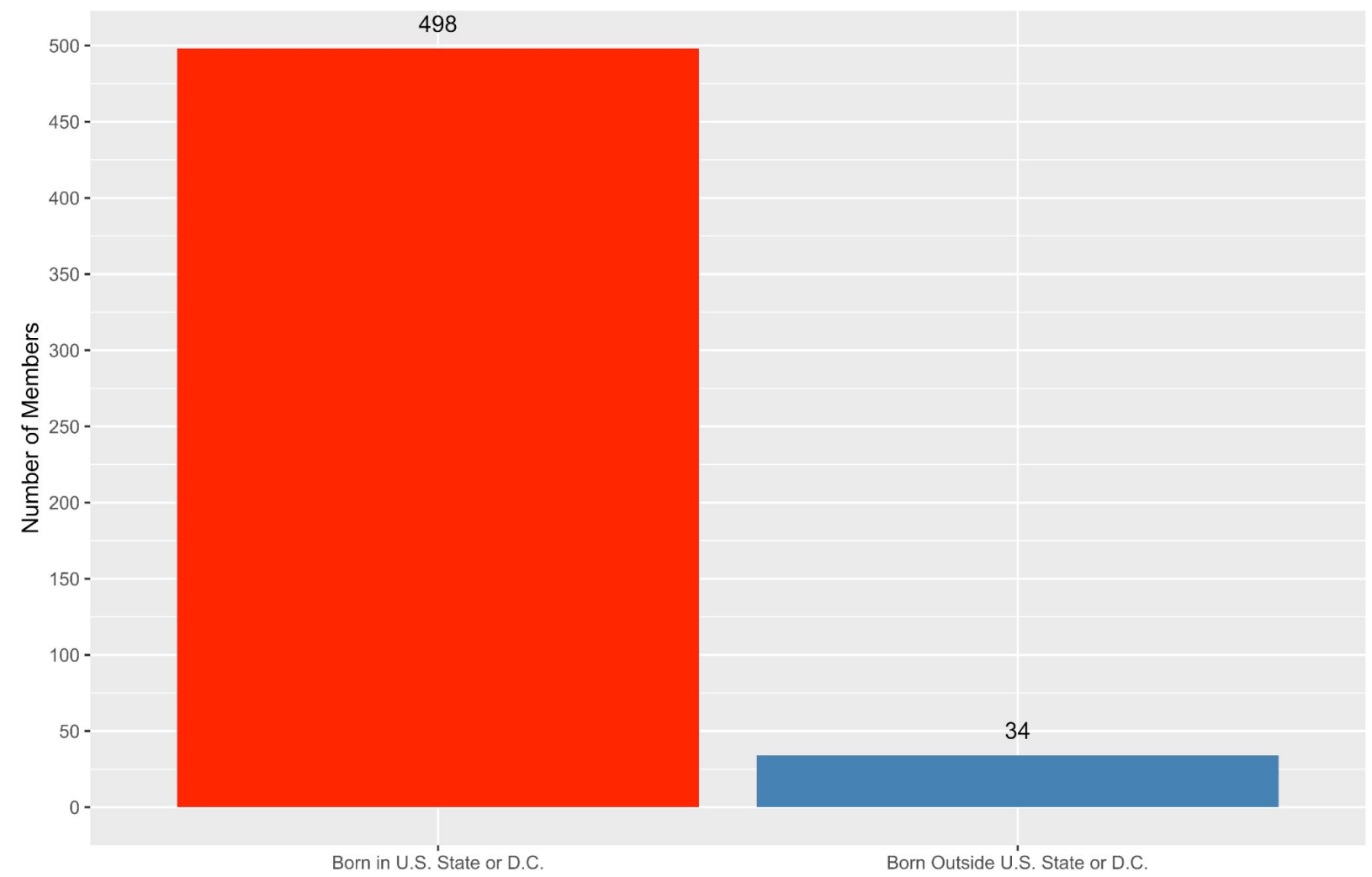

However, according to the U.S. Census Bureau figures from the 2019 American

Community Survey, approximately $8.7 \%$ of all U.S. citizens in the general U.S. population were born outside a U.S. state or D.C. (U.S. Census Bureau 2019). ${ }^{10}$ Thus, if the current U.S.

\footnotetext{
${ }^{10}$ We recognize that individuals who are born in certain U.S. territories, such as Puerto Rico, and are subject to U.S. jurisdiction are U.S. citizens by birth under U.S. law (see 8 U.S.C. § 1402). However, our ability to compare the birthplace of Congressmembers and U.S. citizens in the general U.S. population is limited by the categorization of the U.S. Census data that we use from the American Community Survey, which groups together native U.S. citizens who were "[b]orn in Puerto Rico, [born in] U.S. Island areas, or born abroad to American parent(s).” Thus, we divide the sum of this population $(5,380,391)$ and the naturalized U.S. citizen foreign-born population $(23,182,917)$ by the total U.S. population $(328,239,523)$ to calculate the percentage of the U.S. population born outside a U.S. state or D.C.
} 
Congress reflected the demographics of the U.S. population, an additional 12 voting Members of Congress who were born outside a U.S. state or D.C. would be serving in the U.S. Congress. ${ }^{11}$ Historically, voting members of Congress born outside a U.S. state or D.C. have also been a marginal group, as shown in Figure 2 below. According to our calculations, only about $3.8 \%$ of all voting Members of Congress from the first U.S. Congress in 1789 through the end of the 116th Congress were born outside a U.S. state or D.C.

\section{Figure 2-Voting Congressmembers of Past Congresses by Birthplace}

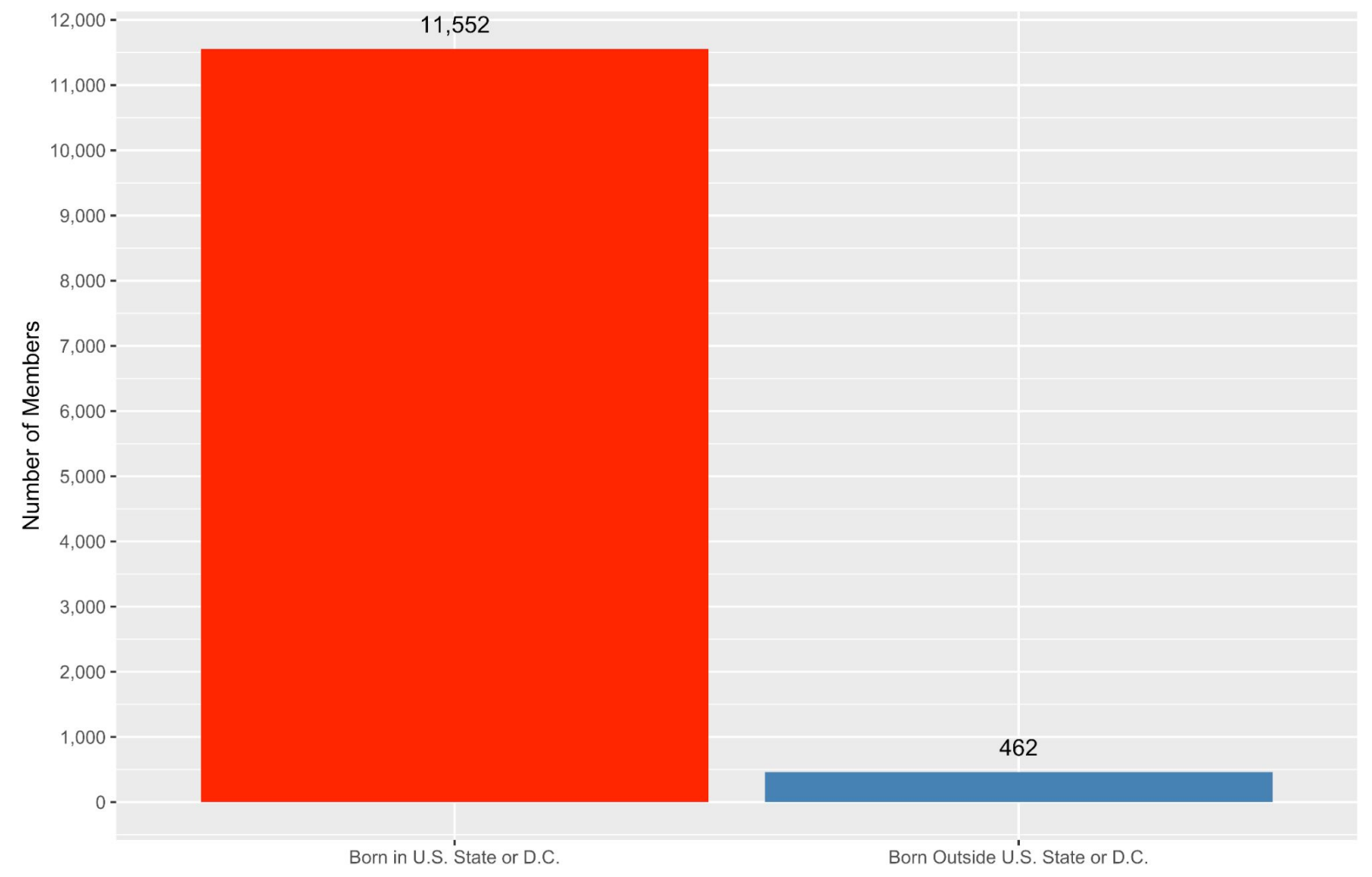

\footnotetext{
${ }^{11}$ We code the demographic characteristics of the current U.S. Congress as of the first day of the 117 th Congress on January 3, 2021. Due to vacancies, there were 532 voting Members of Congress at that time (Manning 2021).
} 
Moreover, despite the ability of immigrants who have become U.S. citizens to hold office, they are largely underrepresented in Congress. As of 2019, 7.1\% of the U.S. population were immigrants who became U.S. citizens (U.S. Census Bureau 2019). ${ }^{12}$ Yet, despite these numbers, only about $3.4 \%$ of voting Members (one Senator and 17 Representatives) in the current Congress are immigrants (Atske 2021). ${ }^{13}$ Thus, if the U.S. Congress reflected the demographics of the U.S. population, an additional 20 voting Members of Congress who became U.S. citizens after immigrating to the United States would be serving in the U.S. Congress.

The U.S. Supreme Court is even more unrepresentative regarding its members' birthplace than the U.S. Congress. All nine current Justices were born in the United States (Federal Judicial Center 2021). Furthermore, the current Court's composition is no historical aberration—with the data we gathered on every U.S. Supreme Court Justice throughout the Court's history, we found that since 1789 only about $5.2 \%$ (6 of 115 ) of all Justices were born outside the United States. ${ }^{14}$ Half of the foreign-born Justices served on the Court during the Founding Era, and since the retirement of Justice Felix Frankfurter from the Court in 1962, not a single Justice who has served on the Court was born abroad.

\footnotetext{
${ }^{12}$ We calculated this percentage by dividing the naturalized U.S. citizen foreign-born population $(23,182,917)$ by the total U.S. population $(328,239,523)$.

${ }^{13}$ While this percentage does not reach the historical apex of immigrants serving in the U.S. Congress during the 1st Congress of 1789-1791 ( 10\%), it remains higher than each of the Congresses from 1967-1974, in which no immigrants served in Congress (Gao \& Bell 2015).

${ }^{14}$ Our dataset that shows our coding of the birthplaces of all the Supreme Court Justices is available in the supplemental materials.
} 
In sum, both Congress and the Supreme Court have been highly unrepresentative compared to the U.S. population in terms of the birthplace of their members. Our rationale for these results is that there is a hidden nativist sentiment among the public. As a way to shed further light on this sentiment, we now turn to the views that the American public maintains about immigration, which we believe are a useful proxy to motivate our expectations for how Americans think about candidates for public office who do not possess prototypical native-born characteristics.

\section{Public Attitudes Toward Immigration}

Immigration has remained a very salient issue in American politics. As immigration rates change along with the demographic structure of the country, the issue is likely to remain as salient or grow in prominence. The topic has become such a flashpoint of politics that parties have oriented a great deal of their messaging around immigration. One of the most prominent examples of course is the rhetoric surrounding limiting immigration in the 2016 election pushed forth by Donald Trump. The idea of "building a wall" along the southern border of the U.S. was seen as a means of curbing immigration, and thereby curtailing the threat of immigrants affecting the relative status of native-born Americans.

A great deal of scholarly attention has been paid to what drives these attitudes (Burns and Gimpel 2000; Sniderman, Hagendoorn, and Prior 2004; Hjerm 2007; Brader, Valentino, and Suhay 2008; Igartua and Cheng 2009). These works often experimentally test the mechanisms behind anti-immigration attitudes. For example, Brader et al. (2008) find that news about a particular immigrant group, Latinos, generates more support for restrictionist immigration policy, and that anxiety is the emotion that most strongly motivates these views. 
Others have analyzed predictors of mass public views about immigration, often through observational studies (Quillian 1995; Hawley 2011; Goldstein and Peters 2014; Flores 2017; 2018). A seminal study in this area finds that sociotropic views about the national economy and views toward racial minorities, not the status of one's pocketbook, are the main predictors of Americans' immigration attitudes (Citrin et al. 1997). Myriad factors including national identity (Newman, Hartman, and Taber 2012), racial views (Sides, Tesler, and Vavreck 2019), and economic senses of threat (Citrin and Sides 2008; Hainmueller and Hiscox 2010) all have been shown to shape these views. Importantly, however, the focus has been overwhelmingly on the motives behind views regarding immigrants in a general sense. Scant attention has been given to the public's views about political elites and immigration in robust ways. This is a major issue because it fails to capture an important political reality, which is that nativist sentiments among the American public with respect to public officeholders have been weaponized.

For example, rhetoric surrounding Representatives who have come to be called the "Squad" (Alexandria Ocasio-Cortez, Ilhan Omar, Ayanna Pressley, and Rashida Tlaib) has been a flashpoint of political controversy. President Trump made remarks to the group to "go back and help fix the totally broken and crime infested places from which they came," which implied that these Representatives did not belong in the United States and that they did not have American interests in mind. The ideas put forth in these comments were that only native-born Americans ought to represent American interests and that those who do not fit a traditional nativist mold do not belong in office.

We view these sentiments as being part of a broader stream of a nativist consensus in American politics against U.S. citizens who do not possess the preferred "homegrown" characteristics of the prototypical native-born American. We conceptualize this consensus as 
manifesting against fellow U.S. citizens who are candidates for public office along three primary axes, which we describe next.

\section{Axes of Americanness}

Among the American public, there exists an abstract sense of belonging to the nation. This idea comes from the American cultural tradition, representation, elite rhetoric, and general ideas about immigrants (Citrin, Reingold, and Green 1990; Frendreis and Tatalovich 1997; Ashmore et al. 2001; Schildkraut 2010; 2014). We expect that these views of belonging motivate nativist candidate preferences, meaning citizens will prefer political elites who match with their sense of belonging. We call these criteria the axes of Americanness. If candidates do not fit within these axes, we expect that they will suffer penalties in support from American citizens.

The first axis is the place of birth. This is one of the first things that comes up in the discussion of nativism in American politics. When Americans think of the important components of a public official, we expect that they are either implicitly or explicitly imagining someone who is born within the United States. As mentioned earlier, part of this expectation could come from the requirements for the executive - specifically, the interpretation of the natural born citizen clause that the president and vice president must be born in the U.S. Regarding the place of birth, we expect that political elites who are citizens but were born outside the U.S. will incur a penalty relative to those born in the U.S. (H1).

The second axis concerns the timing of U.S. citizenship acquisition. This axis is motivated by anti-immigrant views. Americans often express disdain, animosity, or fear of foreigners, which feeds directly into their preferences for who holds office (Brader, Valentino, and Suhay 2008; Avery, Fine, and Márquez 2017; Claassen and McLaren 2019). We anticipate 
that the American public prefers political elites to have acquired U.S. citizenship at birth because of these nativist concerns. We expect that elites who became U.S. citizens as children or adults will incur a penalty relative to those who have been U.S. citizens since birth (H2).

The third and final axis is multiple citizenship status. This axis comes from interpretations of requirements for holding office and anti-immigrant attitudes. American citizens could see those who have dual citizenship as violating key expectations for office. Despite these perceived requirements receiving little comment, we believe that signals from elites about dual citizenship cloud Americans' interpretations_-e.g., Ted Cruz renouncing his Canadian citizenship before running for president in the 2016 election. Additionally, antiimmigrant attitudes also likely motivate this axis because we expect that people with dual citizenship will be viewed with more skepticism because they will be regarded as having allegiance to another country. Though it is possible for a person to have dual citizenship and not be an immigrant, we anticipate that Americans by and large will disfavorably look at elites with dual citizenship and consider them to be "foreign." 15 We expect that elites who hold dual citizenship will incur a loss in support relative to elites who only have U.S. citizenship (H3).

We use two conjoint designs to test the strength of these axes of Americanness. In our first study, we examine how these axes affect support for Senators running for office, among a host of other relevant attributes. This experiment serves as a test of attitudes towards the citizenship status of representatives. In our second study, we focus upon the Supreme Court. This

\footnotetext{
${ }^{15}$ It seems likely that the prospect of negative public opinion towards dual citizenship led U.S. Senator Ted Cruz to renounce the Canadian citizenship that he had acquired by virtue of his birth in Canada. Cruz was also an American since birth because of his mother's U.S. citizenship — and thus was not an immigrant to the United States - yet still decided to relinquish his Canadian citizenship (See Ahmed 2016).
} 
second experiment therefore investigates attitudes about non-representative political elites, which allows us to make better inferences about whether the nativist consensus among the public is limited to representative elites. Next, we describe the design of Study 1.

\section{Study 1 Design}

Our first study investigates the causal impact of citizenship status on the public's preferences for Congressmember candidates. Each candidate profile had nine total attributes, which included "U.S. Citizenship History" which tested H1-2 (whether the candidate was born in the U.S. or abroad and when they became a U.S. citizen) and "Multiple Citizenship Status" which tested H3 (whether the candidate has single or dual citizenship), among a host of other attributes that we anticipated could matter to evaluations of candidate profiles.

The other attributes were as follows: age, profession, gender, ideology, party identification, race, and religion. These were all included in order to control for potential confounders within perceptions of profiles. We expected that participants might make inferences about candidates without particular citizenship characteristics, so these attributes are included to mitigate the potential for omitted variable bias. For example, we include race as another attribute so that we are able to control for the potential inferences that respondents might make about candidates based on the citizenship history attribute - were we not to include race, participants might infer that candidates who were born abroad are nonwhite.

The values for these nine attributes were randomly displayed to respondents. Respondents were given a total of ten scenarios, and within each were provided the following instructions: "Please select which candidate you would prefer to be elected to represent you in the U.S. Senate." The wording of these instructions is deliberate in that it calls to the idea of 
representation. It primes attitudes about who people would like to represent them, and therefore allows us to make inferences about how nativism factors into the preferences Americans have for their representatives.

We conducted this study through the Lucid Fulcrum. Recent studies have shown this online platform to be a very reliable online sample in terms of demographic characteristics and experimental results (Coppock and McClellan 2019). Moreover, a host of other studies on American public opinion have used Lucid (Tomz and Weeks 2020; Lajevardi 2020; Peterson and Kagalwala 2021). We fielded this study on October 29, 2020. Given the proximity to the 2020 U.S. Senate elections, and that this year involved very contentious Congressional races across the country, we expected that attitudes surrounding Congressmembers were very salient. This factor proves advantageous to this study because we have more certainty that respondents considered their substantive preferences for Senators.

We conducted this study with 1,416 respondents who self-identified as U.S. citizens, omitting the six respondents who self-identified as non-citizens. ${ }^{16}$ Each respondent completed ten scenarios, which resulted in 14,160 observations of paired profiles and thus 28,320 total observations. ${ }^{17}$ We next examine the results from this study, in particular the causal impact of citizenship status on candidate preferences.

\footnotetext{
${ }^{16}$ Our sample maps closely with U.S. demographics on the whole; see Appendix 1.

${ }^{17}$ For the sake of comparability across respondents, we include only respondents who completed all ten conjoint tasks. We also omit respondents who did not pass an attention screen at the beginning of the survey.
} 


\section{Study 1 Results}

Within our main analyses, we use average marginal component effects (AMCEs) to test the causal impact of the randomly assigned citizenship attributes on the support given to candidates. Ultimately, it gives us leverage to make inferences about how important the place of birth, timing of citizenship acquisition, and multiple citizenship status are in causally determining the selection of candidates. If the AMCE for one level of an attribute is statistically significant, it is therefore causally important in determining support for a candidate. Previous studies that have employed conjoint design have used this same technique for assessing the causal impact of various attributes (Bansak et al. 2017; Hainmueller, Hopkins, and Yamamoto 2014; Hainmueller, Hangartner, and Yamamoto 2015). Below in Figure 1, we show the AMCEs across the entire sample. ${ }^{18}$

${ }^{18}$ All AMCEs in our analyses cluster standard errors at the respondent level and show 95\% confidence intervals. 


\section{Figure 3-Effects of Candidate Attributes on Probability of Being Preferred for U.S.}

\section{Senate}
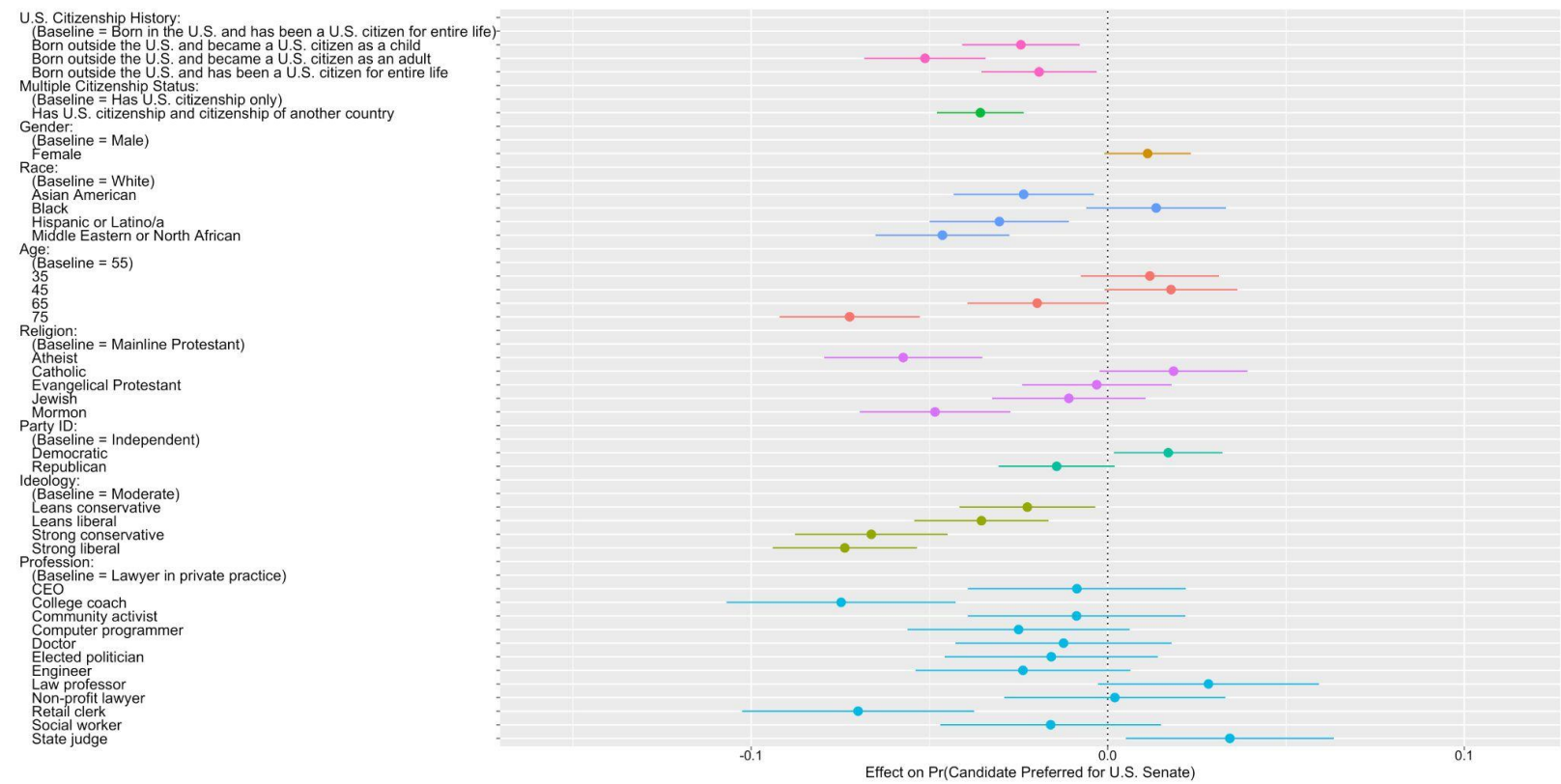

Looking at the U.S. Citizenship History attribute in Figure 3, our results confirm hypothesis 1 . The place of birth of candidates running for the Senate alters support for them among Americans. Candidates who were born in the United States are favored above any candidate born outside the United States, regardless of whether that candidate has been a citizen their entire life, became a citizen as a child, or became a citizen as an adult.

The results also provide support for the second hypothesis that the timing of U.S. citizenship acquisition matters. Candidates who were born outside the U.S. and have been 
citizens their whole lives receive statistically significant stronger support than those who were born outside the U.S. and became citizens as adults $(\mathrm{p}<.001) .{ }^{19}$

In testing our third hypothesis, we assess the effect of multiple citizenship status, in particular a comparison between single and dual citizenship. Looking at the "Multiple Citizenship Status" attribute in Figure 3, we confirm our hypothesis—-that dual citizenship negatively affects support for candidates. All else equal, American citizens favor candidates who have only U.S. citizenship over those who have dual citizenship. This finding, coupled with the confirmation of hypotheses 1 and 2, supports the idea that there is an underlying nativist sentiment in preferences for political elites among the American public.

Overall, the general public expresses a hidden nativist consensus that prefers (1) candidates who were born in the U.S. and have been U.S. citizens their entire lives over candidates who were born outside the U.S. and became citizens as adults and (2) candidates who hold only U.S. citizenship over candidates who hold dual citizenship.

\section{Study 1 Discussion}

The pervasiveness of nativist sentiment in our first study is important for the study of American public opinion. Our confirmations of hypotheses 1-3 show that support among the American public for nativist-oriented candidates is not at all limited to their policy positions. Rather, it also closely relates to who these candidates are as people. Importantly, in the realm of representation, this poses a problem. If candidates incur a penalty for not being prototypical native-born elites

\footnotetext{
${ }^{19}$ For a graphical illustration of these differences, see Figure A-1 in the Appendix 1, which shows the effects of candidate attributes on the probability of being preferred for the U.S. Senate with "Born outside the U.S. and has been a U.S. citizen for entire life" as the "U.S. Citizenship History" attribute baseline.
} 
(i.e., people who were not born in the U.S., did not acquire U.S. citizenship at birth, and/or do not hold only U.S. citizenship), then they risk losing to others who fit those criteria within general elections. This outcome could lead to an overrepresentation of nativist elites, which could have feedback effects resulting in more and more nativist competition throughout American politics.

Moreover, candidates suffering a penalty across the public for not being born as U.S. citizens is a dynamic which sets up a grand problem of representation in public office. These citizens make up nearly a tenth of the American public (Budiman, Noe-Bustamante, and Mark 2020). If the majority of other American citizens have the strong aversion that we find to candidates who immigrated to the U.S. and subsequently became U.S. citizens, then there is the potential for immigrant-citizens on the whole to be underrepresented in government.

These results, however, could be limited to the context of representation. In other words, nativism might be a dimension endogenous to attitudes toward legislators. It is for this reason that we conduct a second study, only this time investigating attitudes toward non-representative political elites-U.S. Supreme Court Justices.

\section{Study 2}

Our second study concerns attitudes about prospective Supreme Court Justices. We use a very similarly formatted conjoint design, with only slight changes for the sake of the design's external validity — we remove party identification and introduce attributes more pertinent to a judge's profile. The main test in this study is the same as in Study 1, which is the importance of citizenship status for political elites. The central difference from our first study is that this 
experiment concerns elites who do not represent particular constituencies, but rather exercise the rule of law.

The timing of this study is also pertinent to its design. It was fielded on October 28 and 29, 2020, which was only days removed from the confirmation of Amy Coney Barrett for the Supreme Court. Indeed, because filling vacancies on the Court was a politically salient issue at the time this survey was fielded, we infer that this salience lends support to our study. American citizens were likely pretreated to think about the processes of the Supreme Court. Even more importantly, they were likely primed to think about the Supreme Court Justice that they would most likely prefer.

Our attributes used in this study are closely aligned with the attributes from Study 1 . We include age, profession, gender, ideology, race, and religion. The only attribute we substitute out from Study 1 is party identification in exchange for education and previous judicial clerkship experience, because party identification is less relevant to Justices on the Supreme Court and we already control for ideology.

Our expectations are the same as in Study 1. They are worth briefly restating in the specific context of Supreme Court Justice candidates. First, we anticipate that elites who were born outside the U.S. will be less favored than candidates who were born in the U.S. (H1). Second, elites who became U.S. citizens at some point after their birth will be less preferred than elites who have been U.S. citizens their entire lives (H2). Third, elites who hold dual citizenship will receive significantly less support relative to candidates who are U.S. citizens only (H3).

In line with the salient issue of Supreme Court nominations when this study was fielded, respondents are instructed to imagine another vacancy on the Court. They are then told, "For each pair of profiles, we'll ask you to select which candidate you would prefer to be nominated 
to the U.S. Supreme Court.” As in Study 1, they review ten separate scenarios and select between two profiles in each scenario.

We conducted this study with 1,399 respondents who self-identified as U.S. citizens, omitting three respondents who self-identified as non-citizens, in order to examine the preferences of only U.S. citizens. ${ }^{20}$ Exactly as in Study 1, each respondent completed ten scenarios, which resulted in 13,990 observations of paired profiles and thus 27,980 total observations. ${ }^{21}$ Next, we turn to our results.

\section{Study 2 Results}

We once again confirm the importance of elites' citizenship history to the general public, only this time in the realm of unelected officials. Across all variants of citizenship history, Supreme Court candidates incur a penalty for being born outside of the U.S. These results confirm hypothesis 1 .

\footnotetext{
${ }^{20}$ Our sample maps closely with U.S. demographics on the whole; see Appendix 2 for the sample demographics.

${ }^{21}$ Similar to Study 1, for the sake of comparability across respondents, we include only respondents who completed all ten conjoint tasks. We also omit respondents who did not pass an attention screen at the beginning of the survey.
} 


\section{Figure 4-Effects of Candidate Attributes on Probability of Being Preferred for U.S.}

\section{Supreme Court}

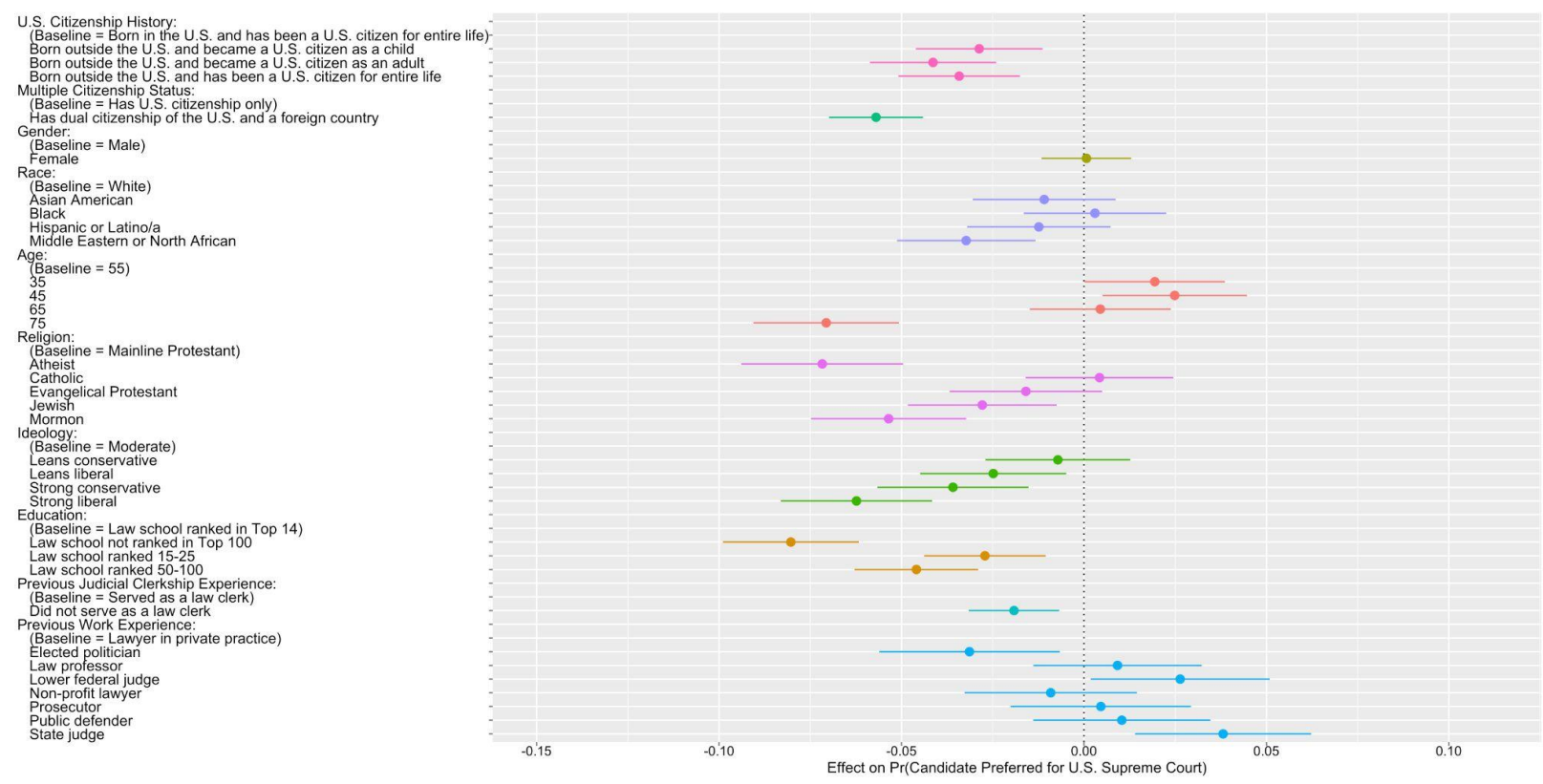

On the whole, we find that American citizens prefer Justices whose place of birth was in the United States. This again is a demonstration that there is an underlying nativist expectation for Supreme Court Justices.

Another point of importance is that the timing of Justices' citizenship acquisition matters little to the support that they receive. Here, we reject our second hypothesis. Specifically, we find no differences in support for Justices who became U.S. citizens as adults relative to (1) those who were born outside the U.S. and have been U.S. citizens their entire lives and to (2) those who became U.S. citizens as children. ${ }^{22}$ This is a point of difference between studies 1 and 2,

\footnotetext{
${ }^{22}$ One can view these results graphically in Figure A-2 in the Appendix 2, which shows the effects of candidate attributes on the probability of being preferred for the U.S. Supreme Court with "Born outside the U.S. and has been a U.S. citizen for entire life" as the "U.S. Citizenship History" attribute baseline.
} 
essentially showing that in the second axis of our theory, the timing of citizenship acquisition is less important than the place of birth for Justices.

Lastly, on multiple citizenship status, we find the public prefers candidates who hold only U.S. citizenship, rather than dual citizenship. These results affirm hypothesis 3. As in Study 1, there is no specification about where the Justice has dual citizenship — and yet, the American public is opposed to simply the prospect of a Justice having dual citizenship.

In sum, similar to Study 1, among the general American public we find there exists a hidden nativist consensus that favors (1) candidates who were born in the U.S. and (2) candidates who hold only U.S. citizenship over candidates who hold dual citizenship. These are a set of hidden criteria for non-representative political elites which, thus far, have not been uncovered.

\section{Study 2 Discussion}

The role of Supreme Court Justices as non-representative elites matters in the larger scheme of this project. Our findings here, in part, work as a robustness check for the idea of a nativist consensus we advance from Study 1. Ultimately, this study demonstrates that representation does not matter to the idea of the nativist consensus. We can infer that citizens are not expressing dislike for elites who do not fit the nativist mold for representation-based reasons-if they were, then we should only see nativist preferences for legislative candidates. However, the public also holds similar views for non-representative elites, who in this case interpret the law of the land.

Despite the lack of a direct electoral connection of the Supreme Court to constituents, the institution's connection to the American public is significant. In particular, candidates for the Court are often constrained by the public in the appointment process. If candidates who do not fit a specific profile are not approved by the public — as we find to be the case among those who 
have non-nativist characteristics - then they might not ever be considered for positions on the Court out of fear of a public backlash.

Across our studies, we find robust preferences among the public for legislative and judicial candidates who possess certain nativist characteristics. These findings show that a nativist sentiment pervades attitudes across branches of government. This, we find, is not an overstated finding. Citizens prefer elites who are American in a very idealized sense of the concept. Although the nativist eligibility requirement set forth for the executive in the natural born citizen clause of the Constitution does not exist in either the legislative or judicial branches, we find in our project that it informally exists among the American public. The codification of nativism into the executive, we theorize, has since been mirrored in how citizens think of their government officials in the other branches. This comes in the form of our confirmation that place of birth matters greatly to the support that representatives and judges receive. We therefore have an overall set of major findings from these two studies when they are paired together. The nativist consensus exists across branches of American government and Americans in the general public. First, the American government has formally mandated that the highest office in the land must fit a nativist mold. And from this, the American public likely has taken institutional cues that elites within the two other branches must also fit the same conception.

\section{Minimal Partisan Heterogeneity}

A strong potential criticism of our findings concerns partisanship. Some might rightly assert that our results do not lend themselves to considering heterogeneity among Democrats and Republicans because our focus is on American citizens at large. For example, Republicans might be more prone to express more nativist sentiments than Democrats because of a more homogenous base of White voters and because of Republican elite rhetoric on nativism. Thus, 
with the following analyses, we include a series of checks on partisan heterogeneity. Ultimately, we find there to effectively be no differences between Democrats and Republicans' preferences for nativist elites, thereby bolstering our theory of a hidden nativist consensus.

First, we review the expressed nativism levels of respondents, which we measured early on within both of our studies. The set of measures we use is taken from Young et al. (2019) and captures negative views toward immigrants and immigration policy. ${ }^{23} \mathrm{With} 0$ as least nativist and 1 as most nativist, we find there to be sizable differences between how Democrats and Republicans score-which is exactly in line with the criticism that there could be a partisan difference in attitudes about elites. ${ }^{24}$ Below, Figures 5 and 6 display nativism in Study 1, and Figures 7 and 8 display nativism in Study 2.

Figure 5-Nativism Distribution

Democrats, Study 1

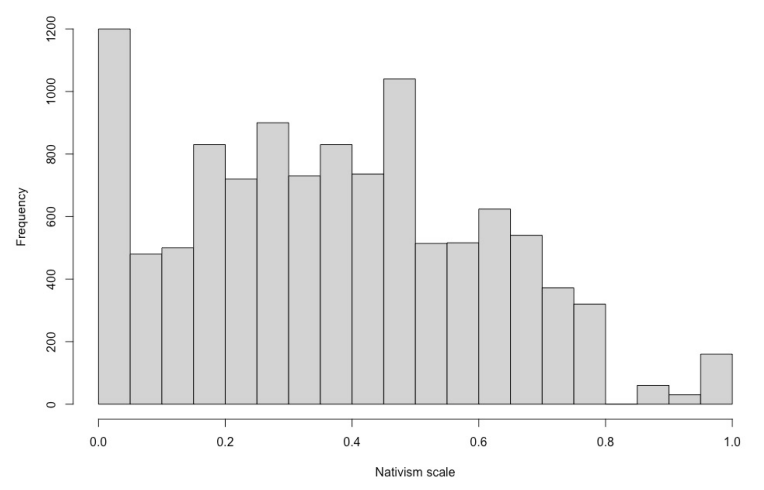

Figure 6-Nativism Distribution

Republicans, Study 1

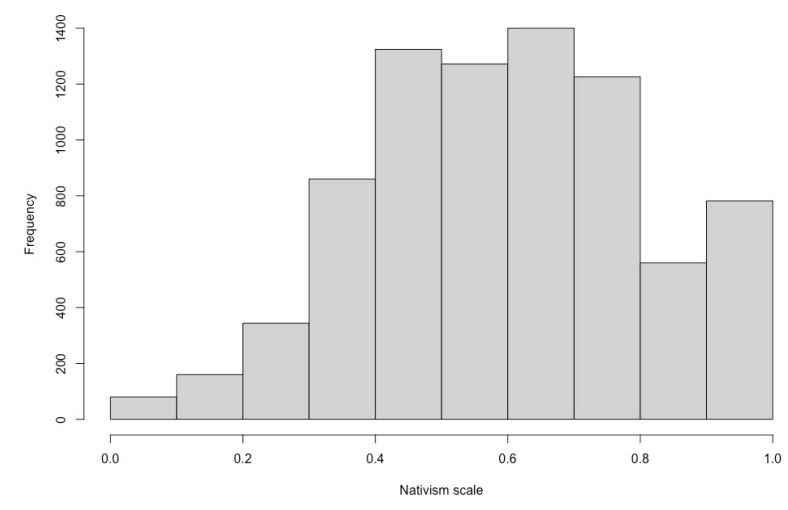

${ }^{23}$ See Appendix 3 for these measures.

${ }^{24}$ We exclude Independent leaners because they are not partisans (Norpoth and Valez 2012). 
In Figures 5 and 6, Republicans express more nativist sentiment than Democrats, based on the skew of the data. We find a similar skew for Democrats and Republicans in Study 2, as shown in Figures 7 and 8 below. By and large, Republicans express more nativist views (with most scores hovering around 0.6 in both studies), whereas Democrats express lower levels of nativism (with most scores around 0.2 to 0.4 in both studies).

Figure 7-Nativism Distribution

Democrats, Study 2

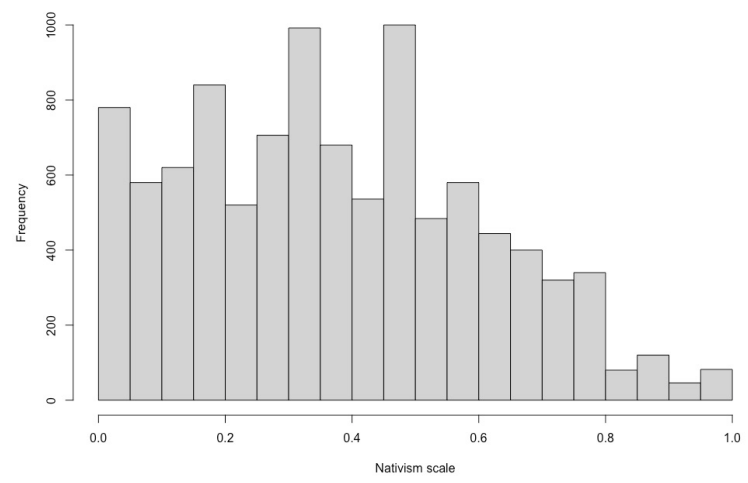

Figure 8-Nativism Distribution

\section{Republicans, Study 2}

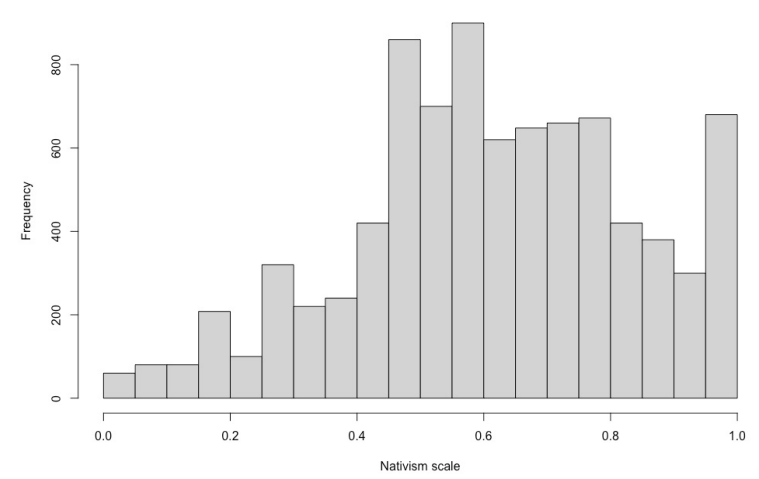

These results confirm that there are partisan differences in nativist views; however, this discussion of distributions might not provide the full story about how this nativism might motivate political perceptions. We therefore conduct a robust test of how nativism affects attitudes towards public elites among partisans through our conjoint analyses, which we turn to next.

We begin by looking at heterogeneity across party lines in Study 1. Shown below in Figures 9 and 10 are the AMCEs for Democrats and Republicans within our first study. 
Figure 9-Effects of Candidate Attributes on Probability of Being Preferred for U.S.

\section{Senate among Democrats}
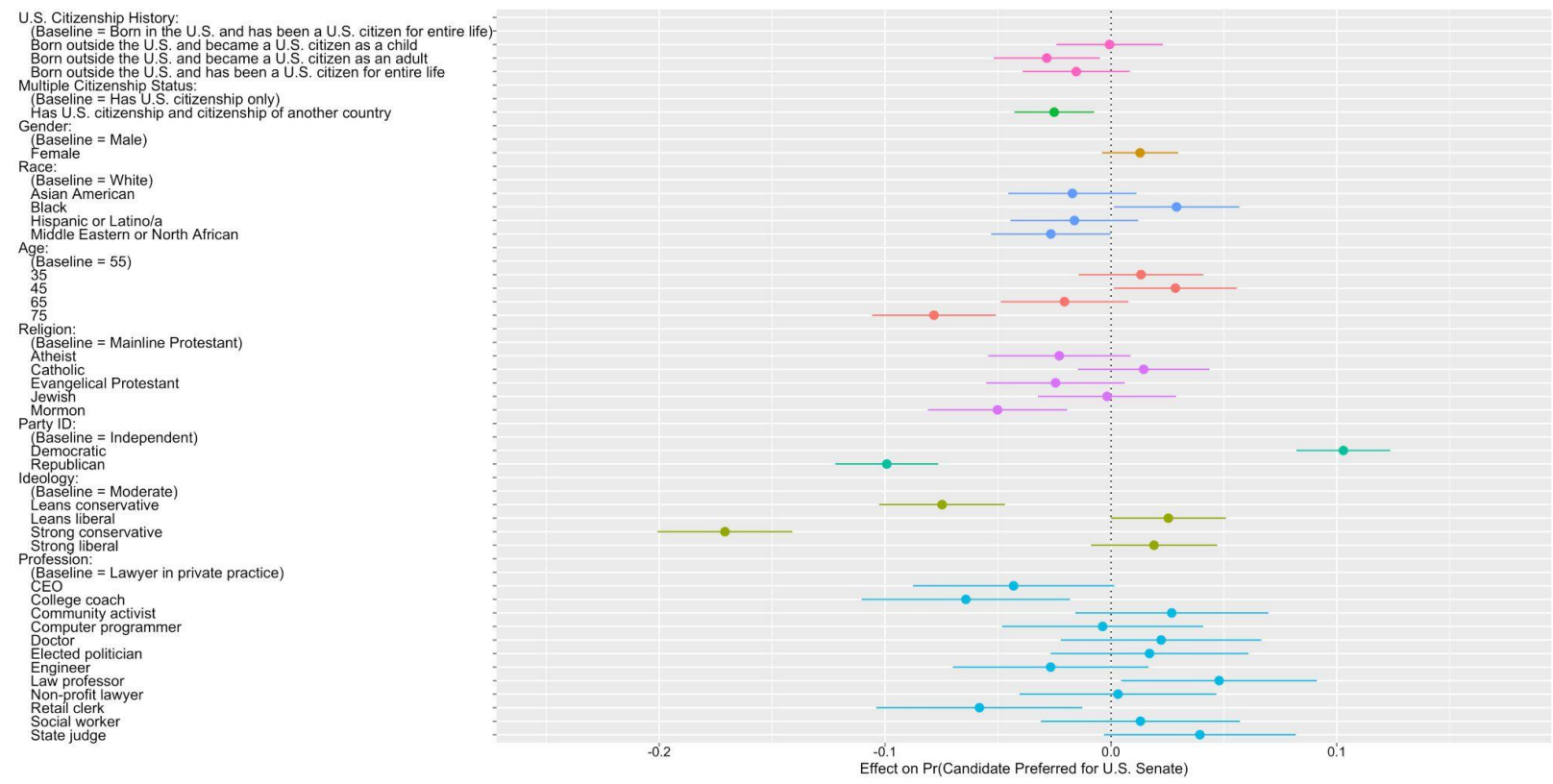

Figure 10-Effects of Candidate Attributes on Probability of Being Preferred for U.S. Senate among Republicans
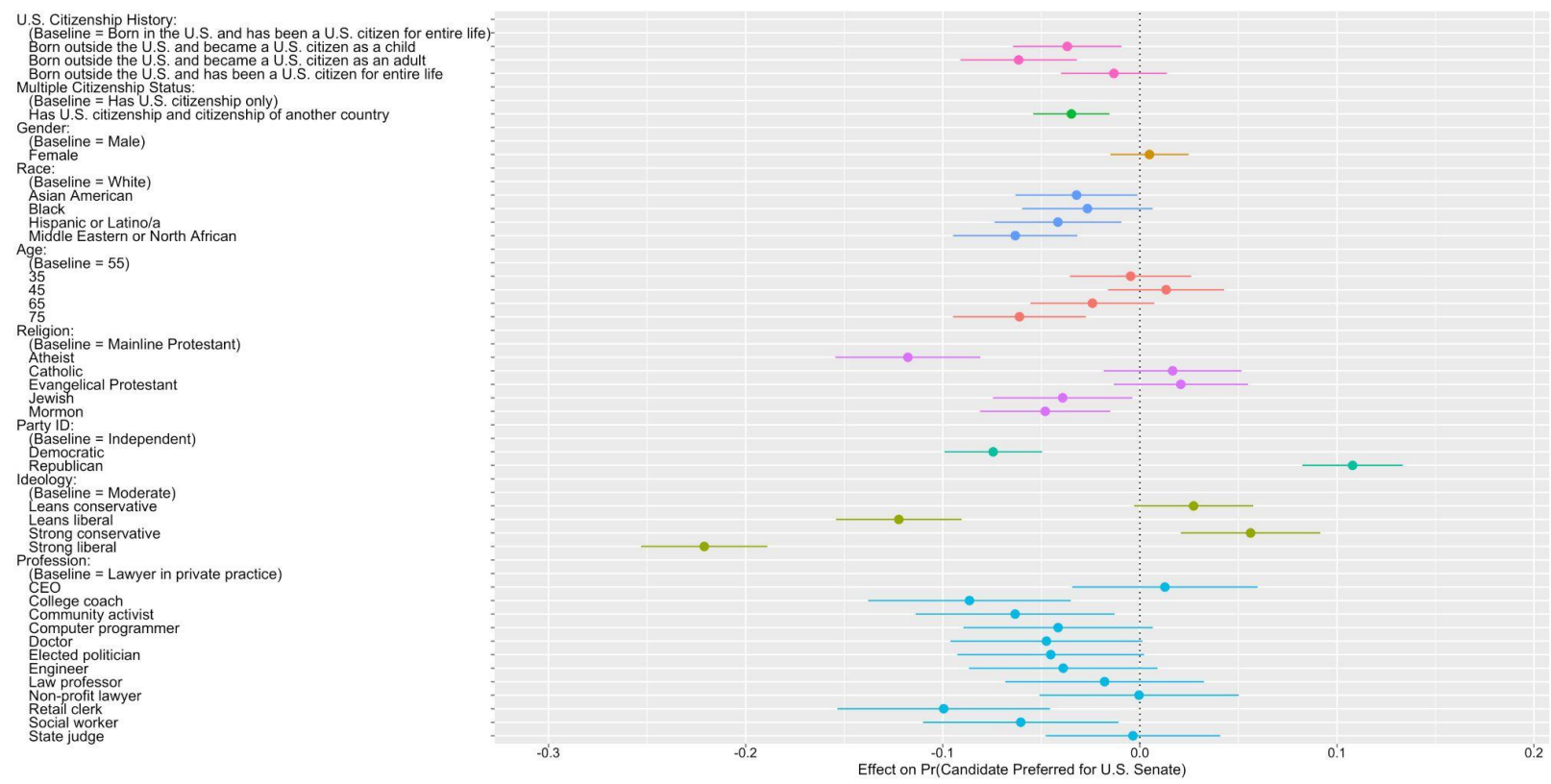
We find that both Democrats and Republicans prefer Senators who have single citizenship over those who have dual citizenship. In terms of the citizenship history attribute, we find slight partisan differences. Both Democrats and Republicans maintain an opposition to legislators born outside of the U.S. who became citizens as adults. However, Republicans are also opposed to those born outside the U.S. who become citizens as children. This slight difference suggests that partisans could be inferring different things about citizenship as it relates to legislators. However, the overall finding in this study is that, despite Democrats expressing less nativism when they are asked, they still maintain very similar views to Republicans in terms of preferred nativist candidates. Lower levels on the nativism scale suggest that Democrats should, in some cases, express similar support for nativist and non-nativist candidates; however, we do not find this to be the case in Study 1. We turn next to Study 2, incorporating the same analysis, which subsets on partisanship and then assesses the AMCEs of Democrats and Republicans.

We again find a substantial lack of partisan differences in our second study. As shown in Figures 11 and 12 below, both Democrats and Republicans are opposed to judicial candidates who were born abroad and have been citizens their entire lives and to judicial candidates who were born outside the U.S. and became U.S. citizens as adults. The only slight difference is that Republicans are also opposed to judicial candidates who were born abroad and became U.S. citizens as children. 
Figure 11 - Effects of Candidate Attributes on Probability of Being Preferred for U.S.

\section{Supreme Court among Democrats}

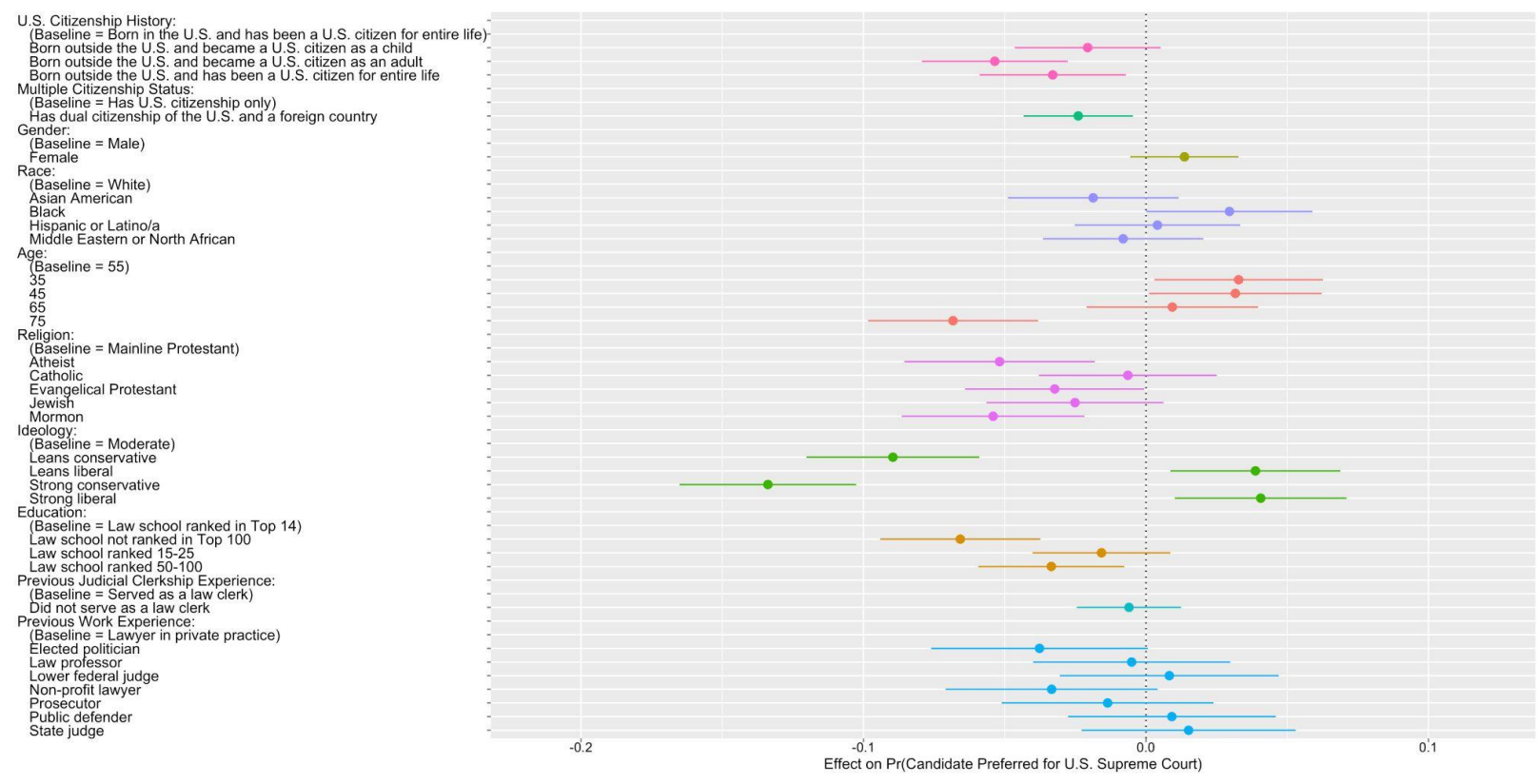

Figure 12 - Effects of Candidate Attributes on Probability of Being Preferred for U.S.

\section{Supreme Court among Republicans}

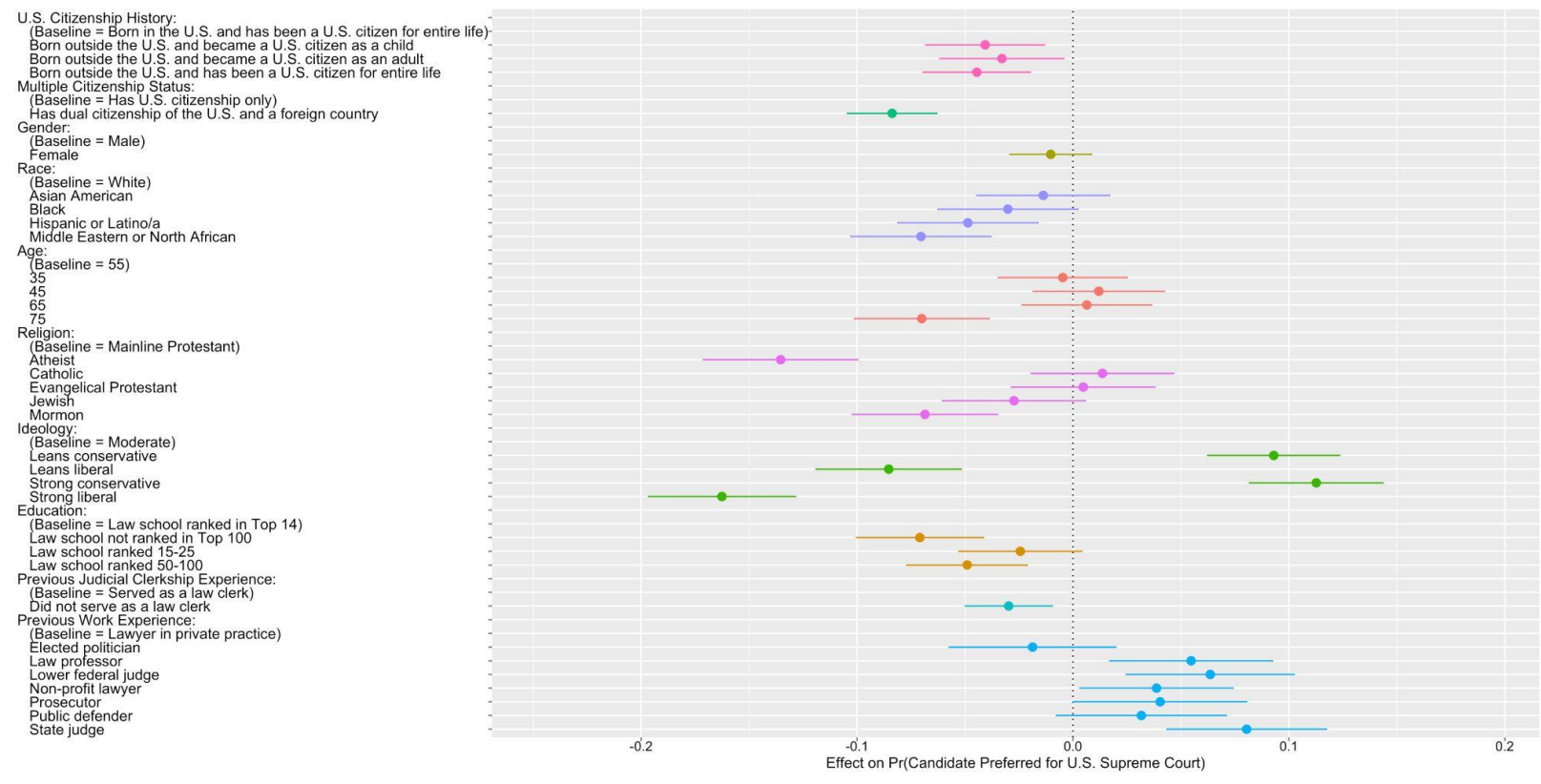


Across both of these analyses, we confirm that nativism is expressed differently between partisans when they are asked, but in their attitudes about elites, partisans have starkly similar nativist preferences. On the whole, this finding lends strong support for our argument that a hidden nativist consensus exists within the American public. Despite the deepening polarization in the U.S., Republicans and Democrats seem to agree along nativist lines for their elite preferences.

This consistency among the public is a call for concern. The inconsistency for partisans between attitudinal measures of nativism and their expressed preferences for elites presents problems for survey research on nativist views. The conjoint designs that we implement provide more behaviorally oriented measures of nativist attitudes, while the survey questions on nativism are attitude oriented. The inconsistency between these essentially calls to ideas about "implicit nativism" among the American public — that is, attitudes that are latent or not typically expressed in standard survey items. This idea of implicit nativism warrants further attention to investigate how pervasive it is among Democrats, as well as the public at large.

\section{Conclusion}

Overall, we show that nativism, in the way of elites' "Americanness," greatly affects which legislative and judicial candidates are preferred by the American public. We show that two innocuous and seemingly apolitical factors of elites' traits are, in fact, very politically consequential. Having dual citizenship and being born abroad shifted public support for representative and non-representative elites at a moment in time when attitudes about these particular groups of elites were very salient. Importantly, a person's birthplace is an aspect of 
their life that is out of their control. Our consistent findings on the penalties that candidates incur for being born outside of the U.S. thus paint a deeply concerning picture about public perceptions of elites - specifically, that a broad swath of Americans (nearly one in ten) faces disfavor in the least and barriers to government positions at most.

The overall similarity of findings across our two large studies shows that this nativist consensus is not a problem limited to discussions of representation. That is, American citizens do not oppose non-nativist elites because they feel that their interests are not represented. Were this the case, then we should only have found support for the consensus in our study on Congressmembers. Instead, nativism exists in more substantive ways. We find it to strongly influence attitudes about two branches of government in ways that have been previously unexplored and deserve significantly more attention.

We find that an underlying nativist sentiment is pervasive among both Democrats and Republicans - despite explicit differences in their expressed levels of nativism. This lends a great deal of support to the idea that these views are more widespread among Americans. For Democrats specifically, our findings demonstrate that they could be explicitly articulating nonnativist views for the sake of social desirability, while being implicitly supportive of these views in practice.

Finally, we theorize that the nativist requirement that is embedded in the very foundation of the U.S. government has likely had reverberating effects on public opinion. The Framers explicitly established a nativist Constitutional bedrock in the original formulation of the United States by mandating that the executive be native-born. We believe that from this original conception the public has, over time, made inferences about elites that often connect closely to 
this sentiment. Nativism might appear to be a recent phenomenon, but it has a longstanding tradition in the threads of the American government. 


\section{References}

Ahmed, Saeed. 2016. "It's Official: Ted Cruz a Citizen of the U.S. - And the U.S. Only." CNN. https://www.cnn.com/2014/06/11/politics/ted-cruz-canada-citizenship/index.html.

Ashmore, Richard D., Lee J. Jussim, and David Wilder. 2001. Social Identity, Intergroup Conflict, and Conflict Reduction. Oxford University Press.

Atske, Sara. 2021. "Immigrants and Children of Immigrants Make Up At Least 14\% of the 117th Congress." Pew Research Center. https://www.pewresearch.org/facttank/2021/02/12/immigrants-and-children-of-immigrants-make-up-at-least-14-of-the-117thcongress/.

Avery, James M., Jeffrey A. Fine, and Timothy Márquez. 2017. "Racial Threat and the Influence of Latino Turnout on State Immigration Policy.” Social Science Quarterly 98 (2): 750-65. https://doi.org/10.1111/ssqu.12326.

Banks, James A. 2017. "Failed Citizenship and Transformative Civic Education.” Educational Researcher 46 (7): 366-77. https://doi.org/10.3102/0013189X17726741.

Bansak, Kirk, Jens Hainmueller, Daniel J. Hopkins, and Teppei Yamamoto. 2017. "The Number of Choice Tasks and Survey Satisficing in Conjoint Experiments.” SSRN Scholarly Paper ID 2916951. Rochester, NY: Social Science Research Network. https://papers.ssrn.com/abstract=2916951.

Brader, Ted, Nicholas A. Valentino, and Elizabeth Suhay. 2008. "What Triggers Public Opposition to Immigration? Anxiety, Group Cues, and Immigration Threat.” American Journal of Political Science 52 (4): 959-78.

Broockman, David E. 2014. "Distorted Communication, Unequal Representation: Constituents Communicate Less to Representatives Not of Their Race." American Journal of Political Science 58 (2): 307-21. https://doi.org/10.1111/ajps. 12068. 
Burns, Peter, and James G. Gimpel. 2000. "Economic Insecurity, Prejudicial Stereotypes, and Public Opinion on Immigration Policy." Political Science Quarterly 115 (2): 201-25. https://doi.org/10.2307/2657900.

Citrin, Jack, Donald P. Green, Christopher Muste, and Cara Wong. 1997. "Public Opinion Toward Immigration Reform: The Role of Economic Motivations.” The Journal of Politics 59 (3): 85881. https://doi.org/10.2307/2998640.

Citrin, Jack, Beth Reingold, and Donald P. Green. 1990. "American Identity and the Politics of Ethnic Change.” The Journal of Politics 52 (4): 1124-54. https://doi.org/10.2307/2131685.

Citrin, Jack, and John Sides. 2008. "Immigration and the Imagined Community in Europe and the United States.” Political Studies 56 (1): 33-56. https://doi.org/10.1111/j.1467-9248.2007.00716.x.

Claassen, Christopher, and Lauren McLaren. 2019. "Do Threats Galvanize Authoritarians or Mobilize Nonauthoritarians? Experimental Tests from 19 European Societies.” Political Psychology n/a (n/a). https://doi.org/10.1111/pops.12720.

Clement, Paul, and Neal Katyal. 2015. "On the Meaning of 'Natural Born Citizen." Harvard Law Review Forum 128: 161-64.

Coppock, Alexander, and Oliver A. McClellan. 2019. "Validating the Demographic, Political, Psychological, and Experimental Results Obtained from a New Source of Online Survey Respondents.” Research \& Politics 6 (1): 2053168018822174. https://doi.org/10.1177/2053168018822174.

Du Bois, W. E. Burghardt. 1998. Black Reconstruction in America, 1860-1880. 12.2.1997 edition. New York, NY: Free Press.

Federal Judicial Center. 2021. "Biographical Directory of Article III Federal Judges, 1789-Present.” https://www.fjc.gov/history/judges.

Flores, René D. 2017. “Do Anti-Immigrant Laws Shape Public Sentiment? A Study of Arizona’s SB 1070 Using Twitter Data.” American Journal of Sociology, October. https://doi.org/10.1086/692983. 
2018. "Can Elites Shape Public Attitudes Toward Immigrants?: Evidence from the 2016 US

Presidential Election.” Social Forces 96 (4): 1649-90. https://doi.org/10.1093/sf/soy001.

Fraga, Bernard L. 2015. "Redistricting and the Causal Impact of Race on Voter Turnout." The Journal of Politics 78 (1): 19-34. https://doi.org/10.1086/683601.

_ 2016. "Candidates or Districts? Reevaluating the Role of Race in Voter Turnout." American Journal of Political Science 60 (1): 97-122. https://doi.org/10.1111/ajps.12172.

Frendreis, John, and Raymond Tatalovich. 1997. "Who Supports English-Only Language Laws? Evidence from the 1992 National Election Study.” Social Science Quarterly 78 (2): 354-68.

Gao, George, and Peter Bell. 2015. "Fewer Immigrants in Congress Today than in Years Past." Pew Research Center. https://www.pewresearch.org/fact-tank/2015/09/23/fewer-immigrants-incongress-today-than-in-years-past/.

Goldstein, Judith L., and Margaret E. Peters. 2014. "Nativism or Economic Threat: Attitudes Toward Immigrants During the Great Recession.” International Interactions 40 (3): 376-401. https://doi.org/10.1080/03050629.2014.899219.

Hainmueller, Jens, Daniel J. Hopkins, and Teppei Yamamoto. 2014. “Causal Inference in Conjoint Analysis: Understanding Multidimensional Choices via Stated Preference Experiments.” Political Analysis 22 (1): 1-30. https://doi.org/10.1093/pan/mpt024.

Hainmueller, Jens, Dominik Hangartner, and Teppei Yamamoto. 2015. "Validating Vignette and Conjoint Survey Experiments against Real-World Behavior." Proceedings of the National Academy of Sciences 112 (8): 2395-2400. https://doi.org/10.1073/pnas.1416587112.

Hainmueller, Jens, and Michael J. Hiscox. 2010. “Attitudes toward Highly Skilled and Low-Skilled Immigration: Evidence from a Survey Experiment.” American Political Science Review 104 (1): 61-84. https://doi.org/10.1017/S0003055409990372.

Hartz, Louis. 1955. The Liberal Tradition in America: An Interpretation of American Political Thought Since the Revolution. Houghton Mifflin Harcourt. 
Hawley, George. 2011. "Political Threat and Immigration: Party Identification, Demographic Context, and Immigration Policy Preference.” Social Science Quarterly 92 (2): 404-22. https://doi.org/10.1111/j.1540-6237.2011.00775.x.

Henderson, John A., Jasjeet S. Sekhon, and Rocío Titiunik. 2016. "Cause or Effect? Turnout in Hispanic Majority-Minority Districts.” Political Analysis 24 (3): 404-12. https://doi.org/10.1093/pan/mpw013.

Hjerm, Mikael. 2007. "Do Numbers Really Count? Group Threat Theory Revisited." Journal of Ethnic and Migration Studies 33 (8): 1253-75. https://doi.org/10.1080/13691830701614056.

Hosenball, Mark. 2012. “Romney’s Birth Certificate Evokes His Father's Controversy.” Reuters. https://www.reuters.com/article/us-usa-campaign-romney-birth-certificate/romneys-birthcertificate-evokes-his-fathers-controversy-idUSBRE84S1GF20120529.

Igartua, Juan-José, and Lifen Cheng. 2009. "Moderating Effect of Group Cue While Processing News on Immigration: Is the Framing Effect a Heuristic Process?” Journal of Communication 59 (4): 72649. https://doi.org/10.1111/j.1460-2466.2009.01454.x.

Kaslovsky, Jaclyn, Jon C. Rogowski, and Andrew R. Stone. 2019. "Descriptive Representation and Public Support for Supreme Court Nominees.” Political Science Research and Methods, 1-16. https://doi.org/10.1017/psrm.2019.59.

Lajevardi, Nazita. 2020. “The Media Matters: Muslim American Portrayals and the Effects on Mass Attitudes." The Journal of Politics, August. https://doi.org/10.1086/711300.

Manning, Jennifer E. 2021. "Membership of the 117th Congress: A Profile." Congressional Research Service. https://crsreports.congress.gov/product/pdf/R/R46705.

Mansbridge, Jane. 2003. “Rethinking Representation.” American Political Science Review 97 (4): 51528. https://doi.org/10.1017/S0003055403000856.

Mansbridge, Jane J. 1999. "Should Blacks Represent Blacks and Women Represent Women? A Contingent 'Yes."' The Journal of Politics. https://doi.org/10.2307/2647821. 
Newman, Benjamin J., Todd K. Hartman, and Charles S. Taber. 2012. "Foreign Language Exposure, Cultural Threat, and Opposition to Immigration.” Political Psychology 33 (5): 635-57. https://doi.org/10.1111/j.1467-9221.2012.00904.x.

Norpoth, Helmut, and Yamil Velez. "Independent Leaners: Ideals, Myths, and Reality.” In The Forum, vol. 10, no. 3. De Gruyter, 2012.

Peterson, Erik, and Ali Kagalwala. 2021. "When Unfamiliarity Breeds Contempt: How Partisan Selective Exposure Sustains Oppositional Media Hostility." American Political Science Review, 1-14. https://doi.org/10.1017/S0003055420001124.

Quillian, Lincoln. 1995. "Prejudice as a Response to Perceived Group Threat: Population Composition and Anti-Immigrant and Racial Prejudice in Europe.” American Sociological Review 60 (4): 586611. https://doi.org/10.2307/2096296.

Reed Amar, Akhil. 2004. “Natural Born Killjoy: Why the Constitution Won't Let Immigrants Run for President, and Why That Should Change." Legal Affairs. https://www.legalaffairs.org/issues/March-April-2004/argument_amar_marpar04.msp.

Rocca, Mo. 2012. “The Original 'Birther' Controversy.” CBS News. https://www.cbsnews.com/news/theoriginal-birther-controversy/.

Schildkraut, Deborah J. 2007. "Defining American Identity in the Twenty-First Century: How Much ‘There' Is There?” The Journal of Politics 69 (3): 597-615. https://doi.org/10.1111/j.14682508.2007.00562.x.

2010. Americanism in the Twenty-First Century: Public Opinion in the Age of Immigration. Cambridge: Cambridge University Press. https://doi.org/10.1017/CBO9780511761249.

- 2014. "Boundaries of American Identity: Evolving Understandings of 'Us." Annual Review of Political Science 17 (1): 441-60. https://doi.org/10.1146/annurev-polisci-080812-144642.

Sen, Maya. 2017. "How Political Signals Affect Public Support for Judicial Nominations: Evidence from a Conjoint Experiment." Political Research Quarterly 70 (2): 374-93. https://doi.org/10.1177/1065912917695229. 
Sides, John, Michael Tesler, and Lynn Vavreck. 2019. Identity Crisis: The 2016 Presidential Campaign and the Battle for the Meaning of America. Princeton University Press.

Slattery, Elizabeth. 2015. "Is Ted Cruz Eligible for the Presidency?" The Heritage Foundation. https://www.heritage.org/the-constitution/commentary/ted-cruz-eligible-the-presidency.

Smith, Rogers M. 1993. "Beyond Tocqueville, Myrdal, and Hartz: The Multiple Traditions in America." The American Political Science Review 87 (3): 549-66. https://doi.org/10.2307/2938735.

-1999. Civic Ideals: Conflicting Visions of Citizenship in U.S. History. New edition. New Haven and London: Yale University Press.

Sniderman, Paul M., Louk Hagendoorn, and Markus Prior. 2004. "Predisposing Factors and Situational Triggers: Exclusionary Reactions to Immigrant Minorities.” The American Political Science Review 98 (1): 35-49.

Teele, Dawn Langan, Joshua Kalla, and Frances Rosenbluth. 2018. "The Ties That Double Bind: Social Roles and Women's Underrepresentation in Politics." American Political Science Review 112 (3): 525-41. https://doi.org/10.1017/S0003055418000217.

Tocqueville, Alexis de. 2003. Democracy in America. Regnery Publishing.

Tomz, Michael, and Jessica L. P. Weeks. 2020. "Public Opinion and Foreign Electoral Intervention." American Political Science Review 114 (3): 856-73. https://doi.org/10.1017/S0003055420000064.

U.S. Census Bureau. 2019. "Selected Social Characteristics in the United States." https://data.census.gov/cedsci/table?q=foreign\%20born\&tid=ACSDP1Y2019.DP02\&hidePrevie $\mathrm{w}=$ false.

Young, Clifford, Katie Ziemer, and Chris Jackson. 2019. “Explaining Trump’s Popular Support: Validation of a Nativism Index.” Social Science Quarterly 100 (2): 412-18. https://doi.org/10.1111/ssqu.12593.

Youniss, James. 2011. "Civic Education: What Schools Can Do to Encourage Civic Identity and Action." Applied Developmental Science 15 (2): 98-103. https://doi.org/10.1080/10888691.2011.560814. 